\title{
Land as airspace: How rezoning privatizes public space (and why governments should not give it away for free)
}

\author{
Cameron K. Murray ${ }^{1}$ and Joshua C. Gordon ${ }^{2}$
}

September 2021

\begin{abstract}
A popular but contested view is that mass rezoning is an essential policy measure to address housing affordability. Often obscured in debates about this measure is that rezoning involves the privatization of public space. We clarify the nature of the policy by recognizing that property rights over land are, conceptually, a bundle of socially negotiated rights to parcels of airspace. This view shows that rezoning to provide rights to airspace for existing landowners is not costless. It involves transferring valuable property rights from the public to existing private landowners for free, creating a more unequal distribution of property rights ownership without necessarily generating faster housing development. We argue that giving away public rights to airspace should not be done for free and explore what policy measures retain value from residential rezoning for the public.
\end{abstract}

Keywords: Housing supply, Zoning, Property rights, Airspace

That's what I do for a living, I sell air... (Finn, 2013)

\section{Planning creates property}

Rising dwelling prices in major cities have spurred intense policy debates (Williams, 2020). One position in this debate holds that a major cause of high dwelling prices is restrictive or "exclusionary" zoning (e.g. Glaeser \& Gyourko, 2018; Metcalf, 2018). In this view, there is an urgent need to rezone vast swathes of urban land to higher densities to spur faster new housing supply and reduce house prices. Single family zoning is particularly maligned, and cities are urged to eliminate this type of zoning in favour of "legalizing" triplexes, fourplexes, and even denser forms of housing (Kahlenberg, 2019; Manville, 2019).

This position has been adopted by politicians and analysts from across the political spectrum. However, it is especially associated with representatives and analysts of the political left. Liberal columnists at publications like the New York Times have repeatedly invoked this argument (Dougherty, 2020; Klein, 2021; Manjoo, 2020), while the Biden

\footnotetext{
${ }^{1}$ Henry Halloran Trust, The University of Sydney, Camperdown NSW 2006. Email: c.murray@sydney.edu.au

${ }^{2}$ School of Public Policy, Simon Fraser University. Email: joshua gordon@sfu.ca
} 
administration in the United States has proposed a $\$ 5$ billion program that will incentivize cities to rezone areas with single family zoning to combat "exclusionary zoning" (Logan, 2021). At the municipal level too, many progressive politicians have urged the "liberalization" of zoning (Badger \& Bui, 2019; Shaw, 2020).

As we will show, these mass rezoning proposals amount to a major privatization of public space. We clarify that land (real property) is best thought of as a set of property rights over airspace, with zoning defining the scope of that airspace through its regulations about building form. In this sense, zoning does not impinge on a landowner's property rights; rather, zoning defines property rights. This previously uncontroversial view of property appears to be widely ignored in current policy debate about the interaction of zoning and housing markets (Penner, 1995).

Rezoning to higher density, therefore, involves a transfer of a property right-to volumetric space and a right to a different use-from the public to an existing private landowner, who formerly owned a different set of property rights at a location. Moreover, by their nature, all private property rights are exclusionary, including newly privatized airspace property rights. Thus, the frequent invocation of "exclusionary zoning" in housing debates may confuse more than enlighten.

What this illustrates, we believe, is a perversion of the typical pattern of left-right politics. The left has usually resisted privatization. What makes rezoning calls by the left quite different to historical privatisations is that in most cases the public is not being compensated for the value of the privatised airspace property rights. There is thus an enormous implicit cost to this policy approach that is being ignored. The value of the property rights given away are equivalent to potential government revenue, since in an alternative policy approach the market value of these rights could be captured by governments.

In what follows, we explain the bundle of rights approach to property and present simplified conceptual diagrams that can be used for educational purposes. The latter illustrate that when land is conceptualized as three-dimensional airspace, upzoning simply involves the expansion of private airspace at the expense of what is currently either public or quasi-public airspace. The literature on land rights also makes clear that the ownership of land is usually highly conditional and constrained in law, which makes transferring it without conditions or compensation a questionable policy move.

We also explain how zoning defines the location of different property rights but not the speed at which those rights are utilized, such as by redeveloping a site into higher density housing. Property rights are a real option-a right, but not an obligation, to undertake the allowable uses. Density (dwellings per unit of space) and the rate of new housing supply (dwellings per unit of time) are conceptually distinct. As an analogy, lane markings on a road that regulate where vehicles must locate are conceptually distinct from speed limits. The rate of new housing supply, known as the market absorption rate, is a built-in speed limit on new housing supply even without planning and zoning regulations, or where there is a large amount of zoned capacity to develop new housing (Murray, 2020, 2021a). Privatizing public airspace not necessarily change any private economic incentives to develop new housing faster.

We then look at the implications of this reconceptualization for policy and note a variety of alternative housing policy options that can address the key issues identified with the privatization of airspace rights for free, such as value capture, incentivising faster market development, and direct housing development alternatives. 
Lastly, we discuss potential explanations for why in the case of mass rezoning there seems to be an inversion of typical left-right politics. Ultimately, greater conceptual clarity about the economics and property rights situation involved in rezoning will help planners to formulate better approaches to foster higher density and faster new housing supply and capture significant value for the public along the way.

\section{The bundle of property rights in three-dimensions}

Despite being a fundamental legal concept, the nature of property is regularly debated and generally regarded as conceptually ambiguous. ${ }^{3}$ One useful way to conceptualise property is as a composite bundle of rights and obligations granted by the state (Baron, 2013). It is thus inherently a collective agreement about the relationship amongst people with regard to the physical world. Property rights are not absolute, nor God-given. They are a product of regulation and law. In the case of land, property usually comprises a bundle of exclusive rights granted to the title holder over the activities within a defined three-dimensional space.

The issue we wish to highlight here is the vertical dimension of real property (land rights). The principle of Cuius est solum, eius est usque ad coelum et ad inferos - a Latin term that means for whoever owns the soil, it is theirs up to heaven and down to hell-is a popular but misleading basis for understanding real property. The vertical extent of property rights to space is not unlimited. It is defined by via statutory and common law. Historically, common law provisions for access to wind or sunlight could limit vertical uses of neighbouring property by allocating those vertical spaces as easements and part of the property rights bundle of the neighbouring property owner. ${ }^{4}$ With the advent of air travel, the rights to the airspace above certain heights become detached from private property rights bundles and reserved for the specific public flying purposes. Rights to space deep underground are also not part of the private property bundle. Tunnels can be built without impinging on private property rights provided they are a sufficient depth.

Nowadays, the three-dimensional nature of property rights is enshrined in the property titles systems of many countries (Karki et al., 2013; van Oosterom et al., 2018). In Australia, property can be subdivided in three-dimensions using a volumetric titling system, an example of which is in the top left panel of Figure 1. In this system, the spatial extent of exclusive rights is defined in three dimensions in the title system itself. This approach provides certainty in complex situations, such as buildings situated above roads or rail corridors, or with multiples uses and ownership within the same building structure.

Formalizing the third dimension of property rights was required before creation of condominium towers in large cities could occur, for instance (Harris, 2011; So, 1962). With the legal innovation of the condominium, it was made explicit that rights to distinct parcels of airspace exist. Many cities have rules about view corridors, which are airspace rights owned by the public that exclude fixed buildings being built in the space, such as in Auckland and Vancouver. The protected view rights in Vancouver are shown in the bottom panels of Figure 1. These are airspace rights explicitly reserved for the public through

\footnotetext{
${ }^{3}$ We use the term property to mean a bundle of legal rights rather than physical space or buildings.

${ }^{4}$ In English law the doctrine of "ancient lights" provided that an established period of enjoyment of direct sunlight crossing a neighbouring property could establish an ongoing right to that light by way of an implied easement (Kerr, 1865). This doctrine has been repudiated in the United States, as described in the decision of Fontainebleau Hotel Corp. v. Forty-Five Twenty-Five, Inc. (1959) in the Florida Appellate Court.
} 
planning laws. Railways and subways are often granted airspace rights to pass below and through buildings. Some cities even allow the rights to airspace to be traded independently, such as New York's system that evolved on the back of a 1977 zoning resolution (top right panel of Figure 1).

(a)

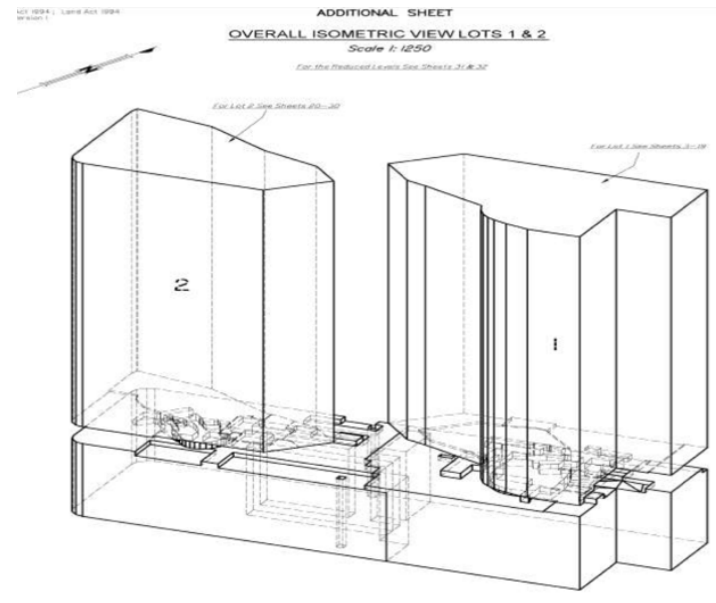

(c) (b)

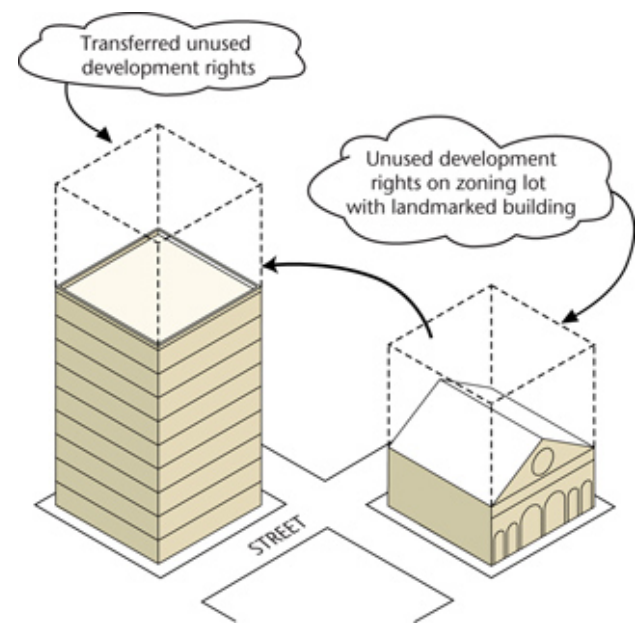

(d)

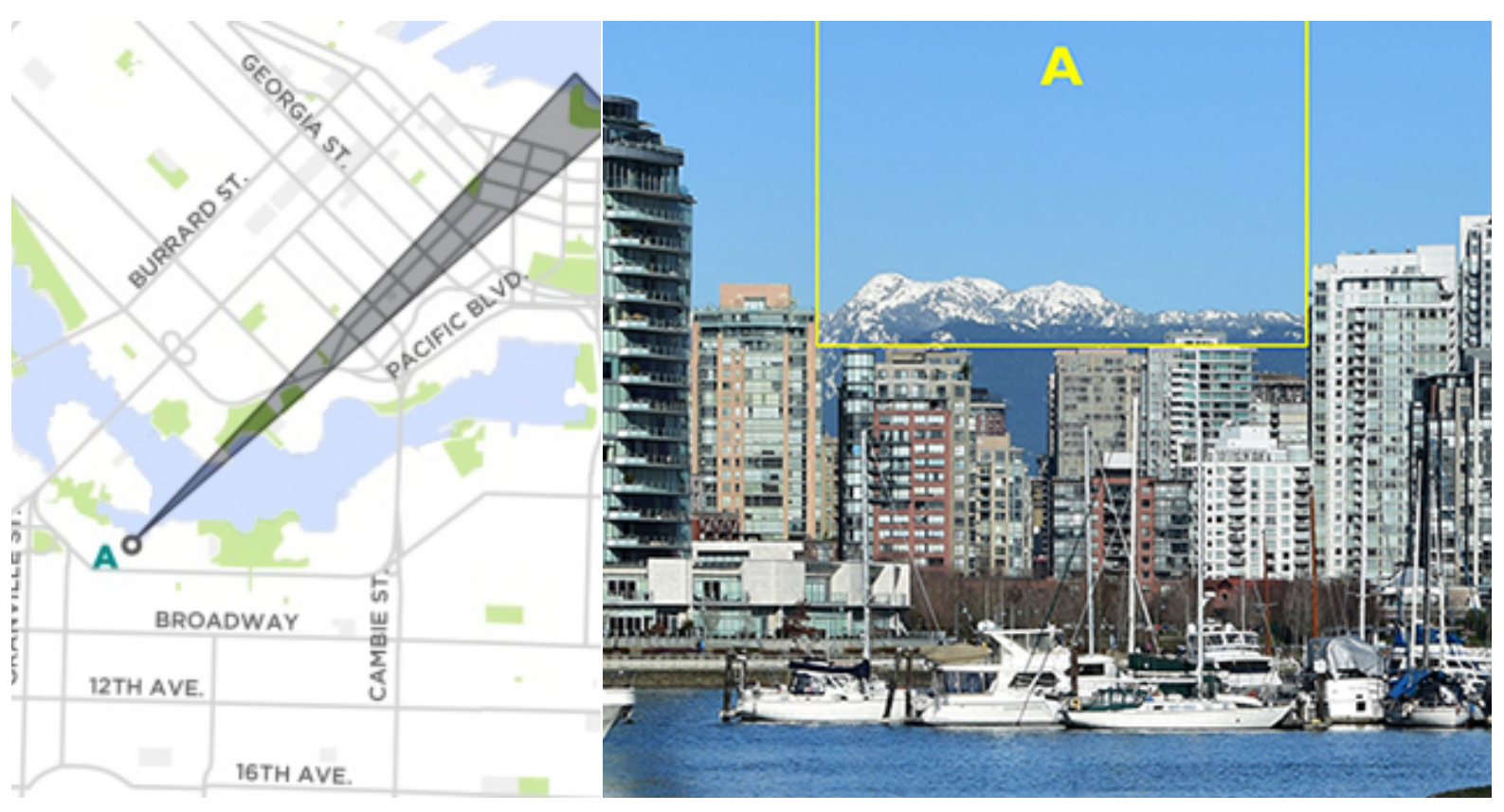

Figure 1: Example of a volumetric title plans in isometric view in panel (a) (Chambers, 2011), a conceptual diagram of New York airspace trading in panel (b) (NYC Panning, 2021), and a Vancouver view corridor in plan view (c) with its volumetric airspace nature shown in panel (d) (City of Vancouver, 2021).

Within the three-dimensional space defined by common and statutory laws, property rights are not absolute. Many national and state governments reserve the rights to minerals and oil and gas located within private property spaces. ${ }^{5}$ Property rights may limit the use of

\footnotetext{
${ }^{5}$ For example Canada retains rights to minerals for "the Crown" (Pearse, 1988).
} 
wild vegetation and animals or the storing or use of certain substances, for example, depending on a variety of local, state, and national laws. Even the right to dispose of property via sale or inheritance is not absolute. Compulsory acquisition (eminent domain) laws exist to avoid hold-out problems from private property owners who refuse to voluntarily sell to the government to allow public works to take place.

The interplay between neighbouring property rights has always been a contested area. In fact, zoning was used to overcame some of the limitations of traditional land use property rights and improve coordination between uses. As Quigley and Rosenthal explain:

Before the 1920s, experimentation with planning and zoning in U.S. cities and towns was sparse and arose primarily as a consequence of the desires of large-tract residential developers to eliminate industrial and commercial activities in their path. With the common law "coming to the nuisance" defense to such property tort claims still intact, developers turned to city councils for relief in the form of authorizing ordinances clearing the way. One such measure adopted in Los Angeles outlawed the operation of a brick kiln in place long before any of the nearby residences were built. The ordinance was upheld in the face of constitutional challenges in the U.S. Supreme Court's 1915 decision in Hadacheck v. Sebastian (239 U.S. 394). Answering the kiln owner's claims of wrongful confiscation of his business, the court remarked, "There must be progress and if in its march private interests are in the way they must yield to the good of the community." (Quigley \& Rosenthal, 2005)

We have so far described the conventional notion of property as a bundle of rights to threedimensional space, and how laws of all types can define the limits to those rights. This legal conceptual background thus leads to the idea of zoning as a set of laws that define the extent of property rights in three dimensions, and thus demonstrate how a policy of mass rezoning amounts to the privatization of public space for free.

\section{Zoning and airspace property rights}

Zoning laws define which rights are in a property bundle and which are not. Typically, zoning rules, like condominium laws and volumetric subdivision, provide tight definitions of the vertical limit to property rights and permissible use types. By defining a vertical limit to private property, zoning also implicitly defines a vertical space above which the right to build is not held by a private property owner, but by the public. This is publicly owned airspace. This is a crucial insight from the property rights approach to zoning.

In Figure 2 we visualise the three-dimensional nature of property rights and the spatial implications of zoning. Conceptually, there are three portions of the vertical space that can be part of private property that are of interest-underground, on-ground, and aboveground. Below and above these spaces are regulated airspace, and public underground space. The left column in Figure 2 shows the different spatial property rights in an apartment/condominium tower. The right to build in the underground, on-ground, and above-ground space are part of the private property rights bundle as defined by zoning and other laws. Within that volume of space, further volumetric subdivisions create spaces that are for the exclusive use of one property owner, and spaces that are owned in common by building owners (for a discussion of the condominium form, see Harris (2011)). These subspaces are defined three-dimensionally, usually with reference to building features.

The centre column shows the case of property where zoning defines a lower vertical limit to building height than the first column. The right to build in that airspace is held by the public. The collective nature of this right means that, for example, a neighbouring landowner 
cannot cantilever a building into that space either, as they do not possess exclusive rights to do so.

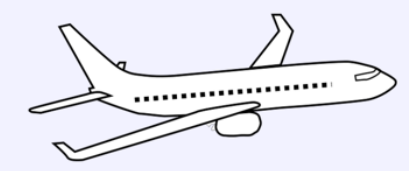

Regulated public airspace

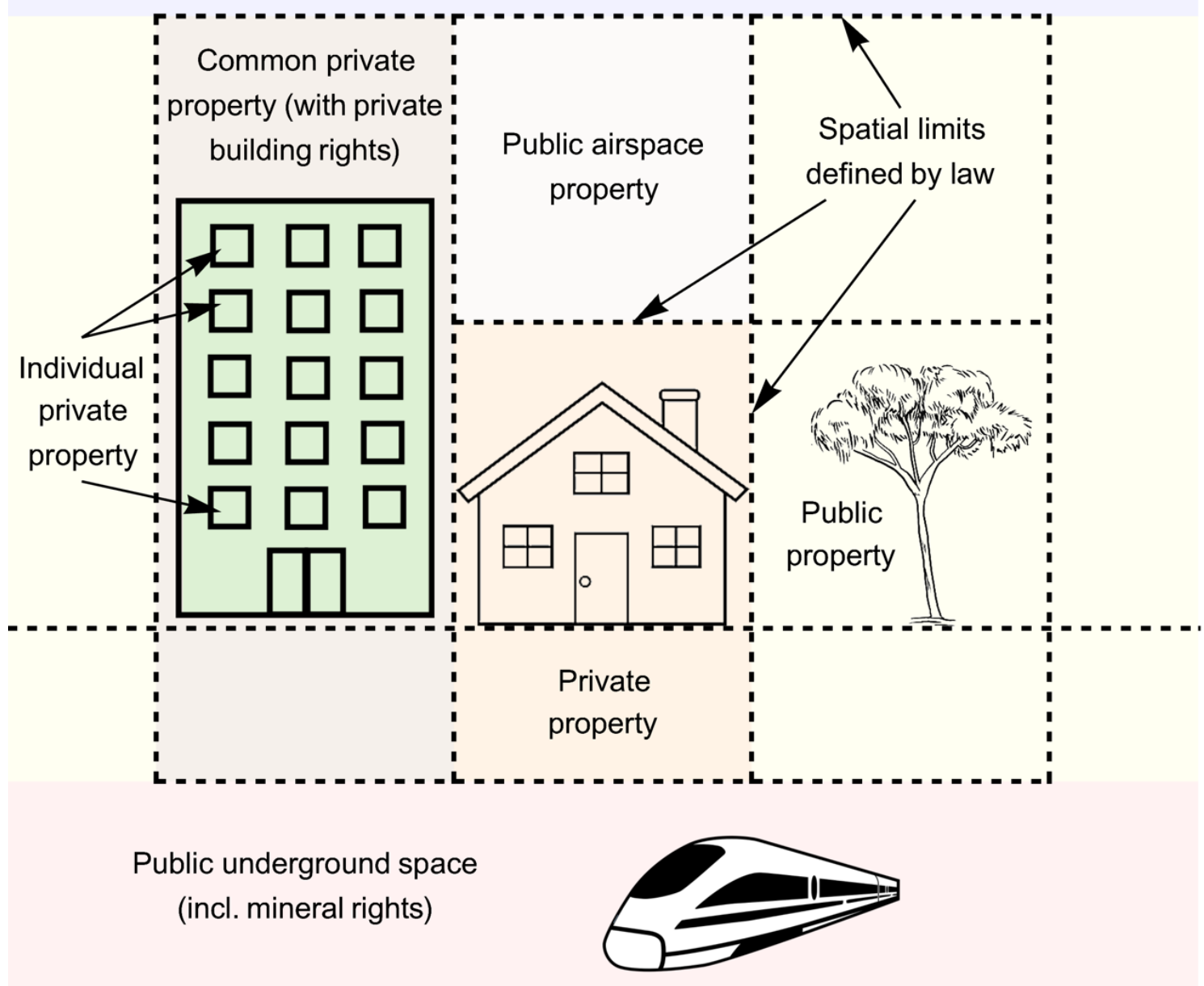

Figure 2: Property as a right to three-dimensional space (author's diagram)

The right column in Figure 2 is a public space, where property rights to all vertical space is held collectively by the public, with access and use rights managed with alternative systems.

This simple three-dimensional conception of zoning and property rights shows that rezoning to allow more intensive building on private property entails a privatization of public airspace. It is little different conceptually from privatizing adjacent space in the form of neighbouring property. The airspace privatisation concept applies generally, even in the case of "missing middle" housing, which typically involves an expansion of building volume rights in parcel of airspace. Even if the vertical building limit does not change, the right to use the airspace more intensively is a new property right, separable from existing rights, and with its own market value. 


\section{The optional nature of property rights}

Property rights in land have the nature of a real option. They confer a right but not an obligation. It is up to the property rights owner to choose if, and when, they develop property by investing in new buildings. This lack of obligation is one of the inherent economic inefficiencies of the property rights systems, and why historical legal debates about the nature of property rights often centred on the principle of "use-it-or-lose-it" provisions (Epstein, 2015; Posner \& Weyl, 2017). Buildings that are economical to build today may be delayed for a variety of reasons, including because investment is irreversible in the short-term. Building a 5-storey building today make it uneconomical to build a 10storey building in the medium term, and hence striking the development option comes at a cost of future alternatives that may have higher total economic returns. In practice, this means that there is a limited connection between the amount of so-called "zoned capacity" and the rate of new housing construction (Limb \& Murray, 2020).

This is a relevant insight for the debate about upzoning and housing supply. It is assumed that current zoning rules are a binding constraint and that only by privatising airspace rights will private property owners be able to change the rate of new housing supply. This is the logic behind the policy push for mass upzoning.

However, government reviews into the rate of homebuilding in the United Kingdom have noted that market factors determine the rate of housing supply (Letwin, 2018). Known as the absorption rate, the rate of supply appears unaffected by the density of allowable housing development (Murray, 2021a). Privatizing airspace on the assumption that increased density equates to a faster absorption rate is, therefore, highly questionable. Evidence from private housing developers in Australia confirms that zoned land is managed as a capital asset (it is "land banked"), not an inventory, with development sequenced in a way to maximise total returns on property rights assets over time (Murray, 2020). This means that when prices fall, housing developers reduce supply, creating an automatic speed limit on new market-led development.

A recent analysis of Los Angeles housing development found that only between $0.1 \%$ and $0.3 \%$ of land parcels are developed into new housing each year, in a city where zoned capacity for extra dwellings is greater than the current total stock of housing. Moreover, $45 \%$ of approved developments exceeded zoned capacity via changes to zoning or exemptions (Romem, 2021). The three-fold variation in the rate of supply was driven by market conditions, not zoning.

Thus, the real options nature of property rights means that the privatisation of public airspace may not lead to a change in the overall quantity of new housing supplied by the market each period, which has been a key argument in its favour. This means that the economic redistribution from falling dwelling prices that is usually taken to accompany the policy may not exist, or be minimal, compared to the redistribution of valuable airspace to existing property owners.

\section{Three implications for policy}

\subsection{Airspace has a market value, often a high one}

Airspace (or intensification rights) property rights have a market value, and often a very high one. One study in Australia showed that rezoning of just six areas targeted for more intensive uses in Queensland, Australia, increased property values by $\$ 720$ million (Murray \& Frijters, 2016). Another study highlights the example of a 363 hectare site in $40 \mathrm{~km}$ west of Melbourne that increased in value from $\$ 120$ million to $\$ 400$ million after its rezoning 
from rural to residential (Kendall \& Tulip, 2018). Freemark (2019) looked at upzoning in Chicago and found that it increased property values between $15 \%$ and $23 \%$.

Thus, city upzoning decisions not only decide where different types of housing are built in the future, but decide which existing landowners receive windfall gains due to the value of new airspace rights they are granted. This incentivises landowners to actively invest in either political persuasion or outright corruption to gain these valuable rights (Murray \& Frijters, 2016). ${ }^{6}$

\subsection{Privatising airspace redistributes property rights unequally}

Second, when rezoning occurs the value of those airspace rights goes to existing property owners, not new property owners. This exacerbates the already unequal distribution of property rights ownership seen in most developed countries (Causa et al., 2019).

Though privatising airspace is often thought to have large downwards redistributive consequences, the initial reallocation of property rights from the public is an upwards redistribution of wealth as existing landowners tend to be wealthier. For subsequent market actions that result from mass upzoning to have a downwards redistributive effect, there must be an extraordinarily large effect on the rate of new housing supply above the counterfactual, sufficient to generate large reductions in housing rents.

\subsection{Privatising airspace may have no effect on dwelling supply}

Because upzoning confers the property right to development higher density housing, but not an obligation, it is unclear where there will be noticeable increase in overall new dwelling supply (i.e. across newly upzoned locations and locations with existing zoned capacity). If the situation is that the market absorption rate is the limiting factor on the rate of new supply in a region, then there will be little or no change in total new dwellings, but potentially a change in their composition by location and type. While we certainly support the intensification of urban uses as cities grow and evolve, rather than excessive lowdensity city growth, it is not clear that zoning is a key determinant of the overall rate of housing supply. Even if there are circumstances where mass upzoning has a marginal effect on the rate of new housing supply, it still comes at an enormous cost in the form of the privatised value of airspace rights and is likely to be an inefficient and unequal way to achieve that supply outcome.

\section{Using the public airspace realm for social benefit}

In this section, we suggest ways to ensure that the economic value of airspace property rights that are privatised from rezoning are captured for the public, and how governments can design incentives to accelerate new housing development and address affordability concerns with non-market housing alternatives.

\subsection{Capture airspace value by tax, sale, or public purchase and rezone}

Since upzoning involves a redistribution of valuable property rights to existing landowners, capturing that value for the public can reduce the upwards wealth redistribution that arises

\footnotetext{
${ }^{6}$ Australian anti-corruption regulators regulatory pursue cases involving donations, bribery and extortion by property owners seeking upzoning decisions. Two recent examples are Operation Sandon by Victoria's Independent Broad-Based Anti-Corruption Commission (IBAC) and Operation Belcarra by Queensland's Crime and Corruption Commission.
} 
from it. There are multiple ways to achieve this outcome, and we describe them here with examples, although is this not an exhaustive description.

A first example is the taxation of the value gain due to rezoning, sometimes known as a betterment tax, which retains a portion value of the airspace property right. In the Australian Capital Territory (ACT), when zoning is changed to allow higher value uses at a location, property owners must "buy" the property right necessary to rebuild to that newly allowable use from the ACT government in the form of a Leave Variation Charge (LVC). It is applied at a rate of $75 \%$ to a tax base that is calculated as the difference in value of the current property right, assuming only the current use is the allowable use, and the new property right for the higher value use. In a city of less than 500,000 people, this has recently raised $\$ 50$ million per year on average (Murray, 2021b).

In Sydney, Australia, between 1969 and 1973 a tax of 30\% of the value difference between rural zoned property rights and urban zoned rights was enacted, payable on conversion of land use (Archer, 1976). It raised $\$ 12$ million but faced fierce political opposition. Great Britain at various times enacted a betterment levy at rates between $40 \%$ and $75 \%$ since the 1909 town planning system was introduced, but like the case of Sydney, the interests of property owners prevailed, and they politically manoeuvred to quickly repeal the taxes (Plimmer \& McGill, 2003). In 2021, variations of this betterment tax concept are being proposed by governments in New South Wales and Victoria.

In the City of Vancouver, for most rezoning proposals, the municipal government attempts to capture around 70\% of the "land lift" (or land appreciation) associated with a rezoning through what are called Community Amenity Contributions (City of Vancouver, 2018; Moore, 2013). This can take the form of either direct cash transfers or the delivery of inkind contributions, such as the provision of community centres or park upgrades. During the recent building boom, the City brought in hundreds of millions in revenue or "public benefits" each year (City of Vancouver, 2018). Although some areas of the city have a preset CAC rate, in many cases contributions are negotiated on a case-by-case basis. This system relies on an administration that is committed to meeting the stated ambitions regarding land lift capture, however, the way contributions are calculated is often hidden from public view.

A second way to capture the value is to sell airspace rights. São Paulo, Brazil, sells right to build to higher density in city areas targeted for densification and redevelopment. Though these recover the value of airspace property rights, they do no change investment timing incentives. The World Bank describes the system as follows:

The city of São Paulo, for example, has used an instrument called Certificados de Potencial Adicional de Construção, or CEPACs (translated as certificates of additional construction potential bonds) as a tool to create development rights for upzoning. The city then sold these rights to developers to raise funds to finance infrastructure construction. The total number of CEPACs, which is capped by law, is determined by the municipality. CEPACs can be used only in certain designated areas that the city government has targeted for public investments. One attractive feature of CEPACs from the developers' perspective has been that they are not required to undertake their development projects immediately after the acquisition of building rights. Instead, they can decide on the timing of their investments according to market conditions. (World Bank, 2021)

The New York airspace trading system is somewhat unique in that it firstly gives airspace rights to landowners who are then able to trade them independently of the rights to existing uses (Finn, 2013). The risk with this approach is that future policy changes simply grant additional new airspace rights to property owners who have already sold theirs. 
A third way to capture value from airspace rights is for a public agency to purchase, voluntarily or compulsorily, property targeted for intensification of uses. Singapore does this with its public housing provider, the Housing Development Board (HDB). A unique part of Singapore's system is that the private owners of land acquired by the government for public uses do not need to be compensated at market values for their land (Haila, 2015). This opens up a way for governments to claw back value from private landowners in addition to getting the value from the rezoning (and redevelopment) into dense new housing estates.

In the Netherlands, a common system for urban development involves government agencies purchasing property rights in rural uses, then selling the sites with new property rights for higher intensity uses after public works and lot realignments have taken place. This is an approach also adopted in the ACT in Australia, where rural to urban land conversion is solely done by a public developer. It has been calculated that if other Australian states enacted the ACT's combined betterment tax and public ownership systems for capturing upzoning value they would raise \$19 billion annually (Murray \& Frijters, 2017)

Public purchase of land and rezoning can also capture value accruing to property rights owners from transport investments, such as the Hong Kong urban rail (the MTR Corporation). The MTR Corporation owns the airspace and buildings above the rail stations, capturing the economic value of the high accessibility that the new rail stations create via the rents of those buildings. Their business has profited predominantly from their property assets following development and from later management of buildings, enabling a high degree of reinvestment in the transit system and low ticket prices. Rather than the value of the property rights for redevelopment near station locations being granted to existing nearby private landowners, these are predominantly internalised into the transit system. Analysis of MTR corporation profits over time reveals that airspace rights generate the bulk of its profits through property development and management (Aveline-Dubach \& Blandeau, 2019).

\subsection{Inclusionary zoning}

Another approach to generating public benefits from rezoning is inclusionary zoning. Inclusionary zoning requires that a certain proportion of new construction be designated for below market rents (or prices), such that low- or middle-income residents can afford them. The relatively affordable units are the main public benefit, as well as the mixed income neighbourhoods which such an approach can help foster (Schuetz et al., 2011).

These policies come in a variety of forms (see e.g., Ramakrishnan et al., 2019). They mainly vary in terms of the share of units that must be below market, the extent of that discount, and the length with which those units will be held at below market rents (in the case of rental units). There are also often rules which govern what size of new developments such an approach would apply to, as well as regulations about the units themselves (e.g., whether they must be indistinguishable from the market rate units, whether they need to be located in the same building, etc.). They are typically imposed by local governments, and there are usually various inducements to developers to incentivize adoption, in cases where it is not mandatory for all developments. These inducements include faster permit times, lower development charges, and especially "density bonuses", which grant additional units or density on a plot of land - i.e., more significant airspace privatization.

Inclusionary zoning programs have been challenged on several grounds. One criticism is that they slow the production of market rate units, since they represent a "tax" on development, and thereby raise rents overall (for a discussion, see Ramakrishnan et al., 
2019; Schuetz et al., 2011). There is limited evidence for this view, however (Ibid.). Others have faulted inclusionary zoning for being insufficiently effective. In most jurisdictions, relatively few affordable units have been generated, and the below-market discount is either modest or still beyond the reach of many low-income residents (Ibid.). As a result, the hoped-for neighbourhood integration that inclusionary zoning promises has not materialized in a substantial way (see e.g., Zhang, 2019).

Although inclusionary zoning is an important potential tool to capture public benefits from rezoning, its limited existing success serves as a caution. In many programs, the extent to which the below-market units capture a substantial part of the value of upzoning may be questionable, and this may be the result of lacking a clear formula or mechanism which links previous land value to the new (rezoned) land value, as exists in some of the approaches documented in Section 6.1. At worst, inclusionary zoning policies can serve as a virtuous "cover" for major development or density concessions by local governments (see e.g., Condon, 2020).

\subsection{Change development timing incentives}

In addition to capturing the value of airspace rights, one of the challenges of the planning system is that it can change the inter-temporal trade-off faced by property owners in their choice of development timing. Flexible planning systems may incentivise slower development if they allow for denser buildings in the future (Murray, 2021a).

Two possible approaches for changing the timing incentives are as follows. The first is to offer time-limited incentives for development, either through expiring development rights, or through incrementally increasing charges on development which reduce payoffs to future development compared to developing now.

A second approach is the traditional land value tax on the market value of the property right, net of improvements. Most British colonies have inherited some form of land value taxation, as distinct from property taxation which includes the value of buildings and improvements. While land value taxes are traditionally understood as economically efficient from a static perspective, they do change intertemporal incentives to accelerate higher value uses of property rights (Murray \& Hermans, 2021).

These approaches can work in tandem with approaches to recover the value of airspace property rights. For example, in the ACT, betterment taxes and land value taxes exist in parallel without any double counting, as market property values already factor in land value tax obligations.

\subsection{Directly invest in housing development}

A final way to use the public airspace realm for public benefit involves directly housing development by government agencies. Again, this can operate in tandem with other mechanisms to capture value and change dynamic incentives.

Singapore has perhaps the most well-known publicly owned housing developer, the HDB, with $90 \%$ of residents living in a dwelling developed by HDB. These units are sold at construction cost price, facilitated by discounted public mortgages, with each citizen eligible to purchase one dwelling. Most western countries had large scale direct housing development for decades. In Australia, 15\% of new housing was publicly developed in the 1960s (Ryan-Collins \& Murray, 2021).

Modern variations on the theme are possible. For example, one bold possibility is a publiclyowned direct housing developer that could target dwelling rent stability in much the same way that central banks intervene in money asset markets to stabilise the price of money. 
Such a publicly-owned developer could purchase sites and begin construction in a countercyclical manner to stabilise the construction industry, but sell dwellings, either surplus or rentals, in a pro-cyclical manner to dampen market price cycles. Design contests could be used to generate quality outcomes, and the agency could also foster rapid adoption of new building technologies in a sector that is often slow to innovate.

The history of effective direct housing investment, and the scope for radical new approaches, would appear to be favourable policy options for those on the political left looking for a fairer and cheaper housing system. It comes without the privatisation of public airspace, nor the reliance on market processes to operate in an unusual and unlikely way that is, by supplying rapidly in the face of declining rents and prices.

\section{Discussion and conclusion}

A policy of large scale upzoning, without a system to capture a share of the value of these privatised airspace rights, is a questionable proposition. It is a high-cost approach with the foregone privatisation revenue equivalent in budgetary terms to government spending. We believe the main barrier to retaining the public value of new airspace rights is political. Landowners and developers who can get these high value property rights for free (or cheaply) through existing rezoning mechanisms do not want to pay for them.

It is hence a puzzle that segments of the political left, traditionally against the privatisation of public assets, and especially giving them away for free, would be so strongly in favour of this policy. We can only speculate about the reasons for this curious pattern. One factor appears to be a generalized aversion to anything that might be characterized as "NIMBYism". Since NIMBYism has been associated with efforts to limit the public provision of affordable housing in certain communities, opposition to mass rezoning-which is also often justified with NIMBY arguments - then becomes characterized as similarly "exclusionary" and contrary to affordable housing. Yet, as we have argued, direct public provision of affordable housing and mass rezoning are very different policies, since the latter is usually merely an expansion of (volumetric) property rights for existing owners, with no guarantee that supply will accelerate and lead to lower market prices or rents.

Building upon a shared disdain for alleged "NIMBYism", a new clever rhetorical strategy has been employed by actors aligned with the development industry. Claims about "legalizing housing", creating a "diversity of housing form", fighting "exclusionary zoning", and achieving "spatial equity" - common pro-rezoning refrains in the academic debate and on social media - play upon left-wing sympathies for the ascendant identity politics of "equity, diversity and inclusion" and liberal social policy (e.g., legalization). This language is particularly employed by the so-called YIMBY movement, which has sprouted up in several countries in recent years, often with the encouragement of the development industry (Bronstein, 2018; Shaw, 2020).

Yet, while YIMBYs usually claim to represent renters, the preferred policy option of mass rezoning will primarily benefit established landowners, at least in the absence of strong mechanism to capture public value. It is important then that policy makers think clearly about the implications of mass rezoning. Reconceptualizing land as airspace will, we hope, help to demystify some of the existing rhetoric that surrounds proposals for large-scale rezoning. 


\section{References}

Archer, R. W. (1976). The Sydney Betterment Levy, 1969-1973: An experiment in functional funding for metropolitan development. Urban Studies, 13(3), 339-342.

Aveline-Dubach, N., \& Blandeau, G. (2019). The political economy of transit value capture: The changing business model of the MTRC in Hong Kong. Urban Studies, 56(16), 3415-3431. Badger, E., \& Bui, Q. (2019, June 18). Cities Start to Question an American Ideal: A House With a Yard on Every Lot. The New York Times.

Baron, J. B. (2013). Rescuing the bundle-of-rights metaphor in property law. University of Cincinnati Law Review, 82, 57.

Bronstein, Z. (2018, September). California's "Yimbys": The Growth Machine's Shock Troops. Dollars \& Sense.

Causa, O., Woloszko, N., \& Leite, D. (2019). Housing, wealth accumulation and wealth distribution: Evidence and stylized facts.

Chambers, L. (2011). Development titling: What planners need to know (a legal perspective) [Presentation of Planning Institute of Australia]. Allens Arthur Robinson.

City of Vancouver. (2018). Annual Report on Community Amenity Contributions and Density Bonusing [Staff report]. https://vancouver.ca/home-property-development/communityamenity-contributions.aspx.

City of Vancouver. (2021). Protecting Vancouver's Views: Alder Terrace view. https://vancouver.ca/home-property-development/alder-terrace-protected-view.aspx Condon, P. (2020). Vancouver's incentives to get affordable homes built are too rich. The Tyee.

Dougherty, C. (2020, February 13). Build Build Build Build Build Build Build Build Build Build Build Build Build Build. New York Times.

Epstein, R. A. (2015). Property Rights in Water, Spectrum and Minerals. Colorado Law Review, 389.

Finn, R. (2013, February 22). The Great Air Race. New York Times.

Freemark, Y. (2019). Upzoning Chicago: Impacts of a Zoning Reform on Property Values and Housing Construction. Urban Affairs Review, 1078087418824672.

Glaeser, E., \& Gyourko, J. (2018). The Economic Implications of Housing Supply. Journal of Economic Perspectives, 32(1), 3--30.

Haila, A. (2015). Urban land rent: Singapore as a property state. John Wiley \& Sons.

Harris, D. C. (2011). Condominium and the city: The rise of property in Vancouver. Law \& Social Inquiry, 36(3), 694-726.

Kahlenberg, R. D. (2019). How Minneapolis Ended Single-Family Zoning. The Century Foundation.

Karki, S., Thompson, R., \& McDougall, K. (2013). Development of validation rules to support digital lodgement of 3D cadastral plans. Computers, Environment and Urban Systems, 40, 3445.

Kendall, R., \& Tulip, P. (2018). The Effect of Zoning on Housing Prices (Issues 2018-03).

Kerr, R. (1865). On ancient lights: And the evidence of surveyors thereon: With tables for the measurement of obstructions. J. Murray. 
Klein, E. (2021, April 19). The 'New Redlining' Is Deciding Who Lives in Your Neighborhood. New York Times.

Kolnick, K. A. (2008). Order before zoning: Land use regulation in Los Angeles, 1880-1915. University of Southern California.

Letwin, O. (2018). Independent Review of Build Out Rates: Draft Analysis. London: Ministry of Housing Communities and Local Government.

Limb, M., \& Murray, (2020). We zoned for density and got higher house prices: Supply and price effects of upzoning over 20 years. Open Science Foundation Pre-Print.

Logan, E. B. (2021, May 19). Biden targets housing rules that hurt low-income earners. Will the suburbs buy in? Los Angeles Times.

Manjoo, F. (2020, February 5). Let's Quit Fetishizing the Single-Family Home. New York Times.

Manville, M. M., Paavo; Lens Michael. (2019). It's Time to End Single-Family Zoning. Journal of the American Planning Association, 1-7.

Metcalf, G. (2018). Sand castles before the tide? Affordable housing in expensive cities. Journal of Economic Perspectives, 32(1), 59-80.

Moore, A. A. (2013). Trading density for benefits: Toronto and Vancouver compared. Institute on Municipal Finance and Governance.

Murray, C. K., \& Frijters, P. (2017). Game of Mates: How favours bleed the nation. Publicious.

Murray, C. K. (2020). Time is money: How landbanking constrains housing supply. Journal of Housing Economics, 101708.

Murray, C. K. (2021a). A Housing Supply Absorption Rate Equation. The Journal of Real Estate Finance and Economics. https://doi.org/10.1007/s11146-020-09815-z

Murray, C. K. (2021b). Explainer: Taxing rezoning windfalls (betterment). OSF Preprints.

Murray, C. K., \& Frijters, P. (2016). Clean money, dirty system: Connected landowners capture beneficial land rezoning. Journal of Urban Economics, 93, 99-114.

https://doi.org/10.1016/j.jue.2016.04.001

Murray, C. K., \& Hermans, J. (2021). Land value is a progressive and efficient property tax base: Evidence from Victoria. Australian Tax Forum, July.

NYC Panning. (2021). About Zoning: Glossary of Zoning Terms. Department of City Planning, Ney York City. https://www1.nyc.gov/site/planning/zoning/glossary.page

Pearse, P. H. (1988). Property Rights and the Development of Natural Resource Policies in Canada. Canadian Public Policy / Analyse de Politiques, 14(3), 307-320. JSTOR. https://doi.org/10.2307/3550433

Penner, J. E. (1995). The bundle of rights picture of property. UCLA Law Review, 43, 711.

Plimmer, F., \& McGill, G. (2003). Land value taxation: Betterment taxation in england and the potential for change. Paris, France.

Posner, E. A., \& Weyl, E. G. (2017). Property is only another name for monopoly. Journal of Legal Analysis, 9(1), 51-123.

Quigley, J. M., \& Rosenthal, L. A. (2005). The effects of land use regulation on the price of housing: What do we know? What can we learn? Cityscape, 69--137. 
Ramakrishnan, K., Treskan, M., \& Greene, S. (2019). Inclusionary zoning: What does the research tell us about the effectiveness of local action? Urban Institute.

Romem, I. (2021). Technical Summary of Econometric Approach to Estimating Housing Element Site Capacity in the City of Los Angeles (Appendix 4.6 Housing Element 2021-2029 Regression Methodology). City of Los Angeles.

Ryan-Collins, J., \& Murray, (2021). When homes earn more than jobs: The rentierization of the Australian housing market. Housing Studies, Forthcoming.

Schuetz, J., Meltzer, R., \& Been, V. (2011) Silver bullet or trojan horse? The effects of inclusionary zoning on local housing markets in the United States. Urban Studies 48(2): 297329.

Shaw, R. (2020). Generation Priced Out: Who Gets to Live in the New Urban America, with a New Preface. University of California Press.

So, F. (1962). Condominium (Information Report No. 159). American Society of Planning Officials.

van Oosterom, P., Erba, D. A., Aien, A., Grant, D., Kalantari, M., Karki, S., Shojaei, D., Thompson, R., Muggenhuber, G., \& Navratil, G. (2018). Best Practices 3D Cadastres: Extended version.

Williams, C. (2020, January 16). Housing is at the root of many of the rich world's problems. The Economist.

World Bank. (2021). Transferable Development Rights (Urban Regeneration). World Bank. https://urban-regeneration.worldbank.org/node/22.

Zhang, T. (2019) Making inclusionary zoning more inclusive. Georgetown Journal on Poverty Law and Policy, 27(1): 171-195. 